УДК 821.161.2.0: 689-055.2

DOI https://doi.org/10.26661/2414-9594-2021-1-35

\title{
ОБРАЗ ЖІНКИ-РУКОДІЛЬНИЦІ В УКРАЇНСЬКІЙ ЛІТЕРАТУРІ ХІХ СТОЛІТТЯ (ЗА ТВОРАМИ І. КОТЛЯРЕВСЬКОГО «НАТАЛКА ПОЛТАВКА», Т. ШЕВЧЕНКА «НАЗАР СТОДОЛЯ», О. КОБИЛЯНСЬКОЇ «ЗЕМЛЯ»)
}

\author{
Осіпенко Н. С. \\ кандидат педагогічних наук, \\ доцент кафедри украӥнської літератури, украӥнознавства та методик їх навчання \\ Уманський державний педагогічний університет імені Павла Тичини \\ вул. Садова, 2, Умань, Черкаська область, Україна \\ orcid.org/0000-0002-7542-7821 \\ n.s.osipenko@udpu.edu.ua
}

Ключові слова: жіноча доля, художній текст, праия, вичивання, дівчина.
Стаття присвячена аналізу образу жінки-рукодільниці у творах I. Котляревського «Наталка Полтавка», Т. Шевченка «Назар Стодоля», О. Кобилянської «Земля». Розглядаються людські якості, які уособлюють найкращі риси жіночого характеру: доброту, сердечність і хазяйновитість. Особлива увага приділяється праці, що увиразнює людські чесноти та вдачу. У статті акцентовано увагу на жіночих образах літератури XIX століття, які різняться рівнем життя та поглядами. Як і в реальному світі, так і на сторінках художніх творів кожна героїня має свою долю.

Відповідно до мети статті здійснено аналіз образу жінки-рукодільниці, яку розуміємо як жінку, що займається рукоділлям, у творах І. Котляревського «Наталка Полтавка», Т. Шевченка «Назар Стодоля», О. Кобилянської «Земля». У досліджені наведено приклади з художніх творів про життя і побут українських героїнь, описи дівчат-красунь у вишитому вбранні; сімейні звичаї і обряди, що супроводжуються використанням вишитих рушників, виготовлених самими дівчатами та жінками; охарактеризовано техніки шиття та процес вишивання.

У результаті дослідження образів жінок-рукодільниць у творах I. Котляревського «Наталка Полтавка», Т. Шевченка «Назар Стодоля», О. Кобилянської «Земля» 3'ясовано, що кожна героїня славилася високими естетичними вподобаннями, розвиненими трудовими навичками, опануванням технології виготовлення й оздоблення речей побуту, одягу. Усі ці якості позитивно впливали на їхній авторитет у суспільстві та протилежної статі.

Статус «жінка-рукодільниця» додавав особистості поваги (подекуди навіть спостерігалося поклоніння таланту та трудолюбству), допомагав людині жити, виконувати складну справу життя, ушляхетнював душу, підіймав над посередністю, поліпшував емоційний стан, робив дівчину витонченою, був ознакою готовності до подружнього життя, моральної краси і досконалості.

Аналіз жіночих образів у вищезазначених художніх творах дозволяє зробити висновок, що ідеалом для українських письменників була жінкарукодільниця, берегиня, у якій гармонійно поєднуються працелюбність, зовнішня і внутрішня краса, високорозвинений естетичний смак. 


\title{
REPRESENTATION OF A CRAFTSWOMAN IN THE UKTAINIAN LITERATURE OF 19TH CENTURY (BASED ON THE WORKS "NATALKA POLTAVKA" BY I. KOTLIAREVSKYI, "NAZAR STODOLIA" BY T. SHEVCHENKO, AND "ZEMLIA" BY O. KOBYLIANSKA)
}

\author{
Osipenko N. S. \\ Ph. D. in Pedagogy, \\ Associate Professor at the Department of Ukrainian Literature, \\ Ukrainian Studies and Methodology Department \\ Pavlo Tychyna Uman State Pedagogical University \\ Sadova str., 2, Uman, Cherkasy region, Ukraine \\ orcid.org/0000-0002-7542-7821 \\ n.s.osipenko@udpu.edu.ua
}

Key words: woman's fate, literary text, labour, embroidery, girl.
The article deals with the analysis of women's representation in such Ukrainian literary works as "Natalka Poltavka" by I. Kotliarevskyi, "Nazar Stodolia" by T. Shevchenko, and "Zemlia" by O. Kobylianska. The author highlights the human qualities that signify the best traits of the character such as kindness, cordiality and domesticity. It is stated that the labour activity is paid particular attention to as it can accentuate human potential and the temperament.

According to the main aim of the article the author examines the image of a craftswoman, being realized as a woman who is engaged in embroidery and needlework, in "Natalka Poltavka" by I. Kotliarevskyi, "Nazar Stodolia" by T. Shevchenko, and "Zemlia" by O. Kobylianska.

The article emphases the woman images in the literature of the 19th century. The author states that they are different according to living standards, temperaments and point of view. Similarly to a real person, each heroine follows her own destiny in works of art.

The study also provides examples of Ukrainian heroines' everyday life, descriptions of beautiful girls in embroidered clothes, family customs and rituals accompanied by the use of embroidered towels, made by the girls and women themselves. Besides, sewing techniques and embroidery process have been characterized.

After examining the craftswomen representation in "Natalka Poltavka" by I. Kotliarevskyi, "Nazar Stodolia" by T. Shevchenko, and "Zemlia" by O. Kobylianska, the author concludes that the heroines had high aesthetics, which was highly valued in the people's worldview. Besides, they were skilled in various activities and technologies of manufacturing and decoration of household items, clothes, that gave them prestige in the society and commitment of the opposite sex.

Consequently, the status of a craftswoman added respect to the individual (in some places there was even a worship of talent and hard work), helped a person to live and to overcome difficult tasks of life, ennobled the soul, improved emotional state, made a woman elegant, was a sign of moral beauty and perfection.

The examined literary texts allow concluding that an ideal for Ukrainian writers was a Ukrainian craftswoman, a guardian of her home and family, who harmoniously combines diligence, exte 
Сьогодення актуалізує потребу переосмислення цінностей та надання об'єктивної характеристики образам класичних творів, а надто жіночих, як орієнтирів щодо сенсу життя, ідеалів, моральних настанов, що характеризують людську душу і відображають епоху, у якій жила і творила особистість, свідомо переймала духовно-етичні цінності й естетичні уявлення рідного етносу.

У літературознавчій науці накопичено значний досвід дослідження жіночих образів. Ця тема була предметом дослідження відомих учених М. Грушевського, М. Євшана, С. Єфремова, М. Костомарова, I. Огієнка, I. Франка, залишається актуальною в сучасних наукових розвідках I. Драча, М. Жулинського, О. Забужко, М. Кудрявцева, С. Максимчук-Макаренко, Г. Шалацької, О. Щербак та інших.

Зазначені автори розглядали образ жінки-матері, жінки-берегині родинного вогнища, жінки, яка $є$ носієм моральних чеснот, жінки-патріотки рідної землі, жінки-вдови, кріпачки, селянки, інтелігентки, представниці певної професії тощо.

На думку С. Сфремова, саме через жіночі образи «найкраще можна пізнати національну вдачу, національний дух, саму навіть національну ідею кожного народу. Адже завжди і всюди жінка творила й охороняла домашне вогнище, під iㅣ доглядом та піклуванням були всі «хатні справи», отже, й традиції роду, а значить, і самої породи певного грунту людей. Саме в жіночих постатях знаходять своє втілення найтиповіші вияви національного духу, найглибші його ознаки та разом i ті загальні змагання, які хвилюють почуття» $[4$, c. 334]. Жіночий образ, на переконання М. Кудрявцева, відіграє у творі значну роль «як суб'єкт нації у виборі моральних орієнтирів, сенсу життя, ідеалів, що визначають злет чи падіння, самоствердження чи деградацію, людяність чи бездуховність, прогрес чи стагнацію» [7, с. 289].

Жіночі типи у творчості українських класиків XIX ст., зокрема Т. Шевченка й О. Кобилянської, розглядав М. Євшан [3]. Окремих особливостей змалювання жіночих образів драми «Назар Стодоля» у системі духовних цінностей першої половини XIX ст. торкалася Г. Шалацька (віддзеркалення духовних цінностей у свідомості окремої особистості, роль жінки-берегині в їхній трансформації за різних умов буття, сутнісні характеристики окремої особи і суспільства загалом) [11]. Образ жінки-матері, жінки-берегині, жінки-воїна, які яскраво і неординарно постають в українській літературі та живописі XIX - пер. пол. XX ст., в українській та європейській культурах, аналізує К. Откович (жіночий чинник в аксіологічному вимірі української духовної культури XIX - початку XX ст.) [9].

Нас цікавив образ жінки-рукодільниці, який став прикметою національної ідентифікації, джерелом вивчення сімейної обрядовості, окремих технік, світоглядних уявлень наших предків про традиційний одяг. Встановлено, що образ жінки-рукодільниці, дівчини-вишивальниці й донині залишається малодослідженим та $\epsilon$ яскравим уособленням народного рукомесництва в українській літературній спадщині.

Мета статті - дослідити та проаналізувати образ жінки-рукодільниці у творах I. Котляревського «Наталка Полтавка», Т. Шевченка «Назар Стодоля», О. Кобилянської «Земля».

Українська жінка в народному світогляді вважається хранителькою сімейного затишку й уособлює в собі найкращі риси характеру: доброту, сердечність і хазяйновитість. Вона завжди славилась як вправна рукодільниця і була майстринею на всі руки. Традиційна вишита сорочка та вишитий рушник, здавна оспівані у фольклорі, вражають своєю унікальністю та донині прославляють Україну на весь світ.

Усна красна словесність величає рукоділля та навчає молодих дівчат працювати: «Не лінуйся, дівонько, рушники вишивати - буде чим гостей шанувати», «Як неділя, то й сорочка біла. Хочеш сорочку мати - не треба зівати», ототожнює красу дівчини з вишитою сорочкою: «Рукави - як писанка, а личко - як маків цвіт» [5, с. 456].

Насамперед зазначимо, що поняття «жінкарукодільниця» розуміємо як «жінка, яка займається рукоділлям» $[10$, с. 906]. А «рукоділля - виготовлення яких-небудь виробів, речей ручним способом; ручна (перев. жіноча) робота» [10, с. 906].

Образ жінки наскрізно проходить через українську літературу, але левова частка творів XIX - початку XX ст. розкриває питання побуту та сімейних стосунків. Полігоном для нашого дослідження стали яскраві зразки класичної літератури XIX ст., у яких зображується доля дівчат і жінок різного стану, змальовуються життя і побут українських героїнь 3 описом дівчат-красунь у вишитому вбранні; згадуються обряди, що супроводжуються використанням вишитих рушників, виготовлених самими дівчатами та жінками; подекуди особливо інформативними $є$ описи технік шиття та вишивання.

У п’єсі І. Котляревського «Наталка Полтавка» головна героїня - дочка Горпини Терпилихи, бідна дівчина, яка кохає Петра, чотири роки вірно жде його із заробітків. Вона не кріпачка, вільна, живе 3 матір'ю, шиттям заробляє собі та матері на життя. Головна героїня не тільки словами, а й піснями розкриває свою вдачу. Пісня «Ой я дівчина Полтавка» - це ліричний автопортрет героїні, простої української дівчини, що подобається своєю красою, веселою та жартівливою вдачею і вірністю всією душею Петрові.

Уже під час першої зустрічі з Возним бачимо, що Наталка розумна, пряма, чесна, відверта, 
Наталку не страшить тяжка праця, аби весь вік жити з коханим.

Доповнює портрет пісня, 3 якої ми дізнаємося, що Наталка небагата, проста, але чесного роду, не соромиться прясти, шити і носити воду:

«Видно шляхи полтавськії і славну Полтаву,

Пошануйте сиротину, і не вводьте в славу.

Не багата я і проста, та чесного роду,

Не стижуся прясти, шити, і носити воду» [6, c. 234].

Про хазяйновитість Наталки вдало говорить Виборний: «Золото - не дівка! Наградив Бог Терпилиху дочкою. Крім того, що красива, розумна, моторна і для всякого діла дотепна, - яке у неї добре серце, як вона поважає матір свою, шанує всіх старших себе; яка трудяща, яка рукодільниця; себе і матір свою на світі держить». I ще він заува-

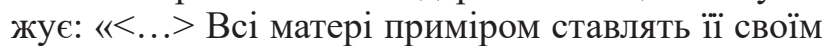
дочкам». «Ай Наталка! Ай Полтавка! От дівка, що і на краю пропасті не тілько не здригнулася, но і другого піддержує» [6, с. 251].

Усе це вказує на те, що в народі високо цінувалися майстерність, естетика побуту, уміння та навички виготовлення й оздоблення одягу. За традицією вважалося, що рукоділля є окрасою дівчини, а опанування техніки крою та вишивки вбрання - готовністю до подружнього життя.

Можна провести паралель між образами Наталки Полтавки та Галі із драми Тараса Григоровича Шевченка «Назар Стодоля». Головна героїня - Галя, дочка пана-сотника, переймає погляди на життя не від свого батька, а від «челяді» та від волелюбного хорунжого Назара. Дівчина весела, по-дитячому жартівлива, наївно вірить у можливість здобути своє щастя. Та $з$ кожною життєвою перепоною Галя мужніє, стає рішучішою. Вона вірна своєму коханому. Їй ніхто більше не потрібен: «Та я й не хочу, щоб на мене другі дивилися!» [12, с. 23].

Коли батько лякає іii, що не дасть приданого, Галя відповідає сміливо і рішуче, що, як і всі, буде заробляти: «Вона сама вишивала [хустку] i гроші на шовк сама заробляла» $[6$, с. 18]. Незважаючи на високий чин батька, героїня не цурається праці - сама вишивала хустки та готувала рушники. 3 мови сватів проглядається прихильне ставлення до дівчини, яка виявляє себе вмілою та працьовитою, рукодільницею: «Спасибі й тобі, дівко, що рано вставала, тонку пряжу пряла, придане придбала» [12, с. 28].

Галя була впевнена, що вміння працювати руками не дасть їй пропасти. Вона ладна краще вмерти, ніж іти заміж за нелюба, противиться бажанню свого батька, його моралі, пориває з ним.

У драмі «Назар Стодоля» автор показав дівчину, яка не підкоряється батькові, не розділяе його поглядів. Образ головної героїні підкреслює той факт, що є жінки, які мають власну думку, обстоюють ऑii, нічого не роблять проти власної волі. I простежується така стійкість характеру в тих, які вміли працювати, займатись рукоділлям.

Отже, героїня відповідає народному уявленню про ідеал, постає як самодостатня особистість. Назар високо оцінює впевненість, любов до праці та безстрашність коханої, уважає, що «кращої іiї нема $<\ldots>$ »» $[12$, с. 38$]$.

У повісті О. Кобилянської «Земля» висвітлено одвічні проблеми - людини і землі, злочину й кари, батьків і дітей. У художньому творі вирізняються образи жінок-трудівниць, жінок-рукодільниць. Серед них Докія, іiі дочка Парасинка, але найяскравіше виділяється образ Анни - наймички, яка завжди знаходила вільну хвилину для душевної справи - рукоділля.

До рукоділля українок у селянських родинах матері та бабусі привчали змалку, визнаючи необхідність цього заняття впродовж усього життя.

У першому розділі повісті, де говориться, що Парасинка дійшла того віку, щоб виходити заміж, з'являються згадки про рукоділля: «Докія ладила вже для неї рушники, постіль і білля. Се останнє шила собі дівчина сама. А як прегарно! Неначе швачка! Коли інші дівчата й жінки перепихали й витягали голку крізь полотно, як патик, вона вживала наперстка й шила такими дрібонькими штихами, мов маком засівала. Окрім того, вишивала на рукавах червоною, жовтою і чорною заполоччю найкращі й найтрудніші взірці з пам'яті, а вкінці складала назад у скриню таке чисте й незім'яте шитво, неначе б не дотикалася його ніколи руками $<\ldots>>\gg[5$, с. 18$]$.

Докія, як і кожна мати, хотіла для єдиної доньки кращої долі. Хоч і руки золоті вона мала, та важко ними на життя заробляти. Шукала мати заможного чоловіка в пару доньці. Мати переконує Парасинку вийти заміж за Тодорика. А та задумалася, чи буде їй до лиця в білім рушнику (серпанку): «Згадала, як то інші дівчата будуть їй завидувати, особливо ті старші, що ось вона вже молодиця! $<\ldots>>$ » $[5$, с. 42$]$.

Цікавим для нашого дослідження є образ Анни. Уперше ми зустрічаємо ії на весіллі в Парасинки. Автор намагається підкреслити, що дівчина мала покладистий характер та була трудівницею: «Анна, панська наймичка, робітниця в покоях, марна й неначе бронзова статуя, стояла скромно в однім куті світлиці недалеко світла й дивилася великими, зворушеними, німим горем переповненими очима нерухомо на одну пару» $[5$, с. 98$]$.

Один із головних героїв - коханий Анни, Михайло. У його родині прийнято було не сидіти без діла та трудитись коло власної землі. Михайло бачив, що Анні будь-яка робота не страшна. І саме iii покохав, хоч знав, що батькам не сподобається його вибір нареченої-наймички. 
О. Кобилянська вдало описує, що саме вражає серце Михайлове. Дівчина була іншою: завше берегла і природню красу, і вже не нові речі. Читач спостерігає за думками Михайла: «Була інша, як другі сільські дівчата. Не знав, саме докладно, чим різнилася від інших, не застановлявся над тим ніколи глибше. Він відчував лише сліпо різницю. Була ніжніша й тонких обичаїв. Була в одежі все чиста, а гарне темне волосся іiї було в порядку» [5, с. 134].

Нерідко Анна ставала об'єктом для розмов. Оцінювали як їі постать, так і вбрання ошатне, яке сама вишивала, і те, що пані дарувала: «По службі, щоправда, зближалися до неї і обступали iii дівчата, оглядали іiї одіж, iï гарно вишиту сніжно-білу сорочку, іiі маленькі срібні ковточки, що дістала одного разу від пані <...> [5, с. 175].

Відчутне у словах автора і співчуття до героїні. Адже в сім'ї Анни саме вона заробляла гроші й відразу відносила матері, а не витрачала на себе: «Мати ж мучила іï та била доти, доки вона не віддавала їх до останнього феника. Таким чином була iï будучність обмежена на працю рук, неустанний пострах перед матір'ю і остротою брата. Пізнання та свідомість великої бідноти, а 3 тим почуття своєї безповоротності настроїли іiі і без того до поваги й думання склонну натуру поважно до глибини душі. Ї̈̈ щоденні сходини з панею і панною, чутливими і благородними жінками, що іiі дуже любили за iï тиху та консеквентну вдачу, відібрало iï єству жорстокість і неповоротність некультурної селянки 3 першої руки, а натомість надало iï поважній душі корму, гнучкості і свого роду інтелігенції» [5, с. 175].

Анна змалку працювала, а із чотирнадцяти років вже наймитувала, автор підкреслює її простоту та повагу до інших: «Не вміла читати й писати. До писання не складалися іï пальці, звиклі лиш до «грубшої» праці, а до читання не ставало часу. Все і всюди манила праця, і свобідних хвиль в іiї скромнім житті не бувало. Та зате заховала ㄲï дівоча душа, із-за умних і щирих наук і присторог благородних жінок, білість і чистоту. Пригадувала дику цвітку, що виростала в затишку лісу, далеко від голосного світу, або диких голубів» [5, с. 203].

Старші, поважні й багатші газдині, як Докія, що бували частіше в панській хаті, любили і ставилися до Анни із прихильністю. Проти них вона була покірна та цілувала їх, коли зустрічалися в неділю і свята, у руки. Їм це було мило, і вони, цілуючи ії в чоло, називали іiї «доньцею», але простіші не мали для неї серця.

Її легкість у роботі хатній, готуванні страв та догляді за речами не раз викликала насмішки 3 боку інших дівчат та жінок: «Вона навчилася в дворі багато, чого вони не знали і чого дівчина не могла затаїти - вигладжувати білля, варити i т. ін., - а що се незнання тої роботи не годилося
3 їхньою гідністю газдинь, то вони глумилися 3 неї і кепкували при кожній нагоді. Вона дивиться лише, аби на ній сорочка була біла, - говорили, але чи ії скриня заповняється біллям, се вже іiі не обходить. Відай, треба буде дві пари волів, аби потягнули іiі скриню до хати чоловікові, як дістане якого, бо одна пара не встигне» [5, с. 212].

Або знов: «Вона вміє білля вигладжувати й наперстком шити, але тим вона не доробиться ані землі, ані чоловіка. До землі треба з сапою приступати, а до чоловіка - 3 повними руками. Але, може, їй придасться коли й наперсток. Лишиться без даху над головою, бо в неї мамка і братчик такі, що за те не тяжко, тоді вона поставить собі його на голову, й він їй стане за покривало <...>» [3, с. 216]. Але і тут наша героїня не втрачає віри в майбутнє: «То добре, що хоч руки були в неї здорові. Ті руки поможуть їй, аби ӥй як тяжко було в житті, бо й що було діяти? Світ для всіх. Для багачів і убогих» [5, с. 218].

Із твору ми дізнаємось, що Анна зійшлась із Михайлом та готувалась до весілля - вишивала сорочку. Хлопець убачав в Анні не лише добру дівчину, але й справну майстриню. Саме тому

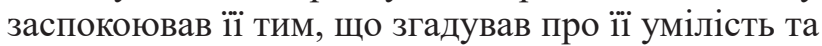
завзятість. Відволікаючи від важких думок, обіцяв спільне життя в сім’ї та достатку: «Від сьогодні за рік будеш ти в мене газдинею і будеш не собі, але мені сорочку шити. I не чорною волічкою вишивати, а самим червоним шовком і хіром, золотом. «Оце ти собі пам'ятай! - сказав він весело. - Журитися нема чого! Що снилося, то снилося! А що я кажу, то вже кажу!». При тих словах вдарив себе п’ястуком у свої груди, що аж задудніло. I, усміхнувшись, розсталися» [5, с. 243].

Та не судилося їм бути разом. Попри втрату коханого та дітей, Анна знайшла в собі сили жити далі. Добра репутація майстрині дала можливість повернутись до Докії та стати ӥй робітницею.

Брат Докії - Петро високо оцінив майстерність Анни: «Руки їі хіба з золотом нарівні поставити!» [5, с. 271].

Отже, авторка виписує яскравий образ дівчини-рукодільниці як умілої та завзятої майстрині, вправної в хатній роботі, готуванні страв та догляді за речами. Спілкування з паннами, їхнє прихильне ставлення до Анни надало їй духовності, толерантності, шляхетності та певної інтелігентності тощо.

У результаті проведеного дослідження образів жінок-рукодільниць у творах I. Котляревського «Наталка Полтавка», Т. Шевченка «Назар Стодоля», О. Кобилянської «Земля» 3'ясовано, що кожна героїня славилася високими естетичними вподобаннями, розвиненими трудовими навичками виготовлення й оздоблення речей побуту, одягу. Статус «жінка-рукодільниця» додавав особистості поваги (подекуди навіть існувало поклоніння 
таланту та трудолюбству), допомагав людині жити, виконувати складну справу життя, ушляхетнював душу, підіймав над посередністю, поліпшував емоційний стан, робив жінку витонченою, був ознакою моральної краси і досконалості.

Перспективу подальших досліджень убачаємо у вивченні образу-жінки рукоділь- ниці в інших творах української літератури XIX-XX ст. На особливу увагу заслуговує художнє зображення народної вишивки, опису народного вбрання, технології виготовлення. Цей матеріал важливий у дослідженні національного світогляду, характеру, естетичних уподобань української дівчини, жінки.

\section{ЛІТЕРАТУРА}

1. Ганжа Д., Гонюк О. Трансформація образу жінки в українській літературі кінця XIX - першої половини ХХ ст. Філологічні науки : збірник наукових праць студентів та викладачів факультету / упор. О. Панченко. Дніпро, 2017. С. 18-22.

2. Демченко І. Особливості поетики Ольги Кобилянської. Київ : Твім-інтер, 2001. 208 с.

3. Євшан М. Жінка в українській літературі. Жени рускі. Дивослово. 2009. № 5. С. 57-60.

4. Єфремов С. Історія українського письменства. Київ : Феміна, 1995. 688 с.

5. Кобилянська О. Земля : повість. Київ : Знання, 2020. 318 с.

6. Котляревський І. Енеїда ; Наталка Полтавка : п’єса. Київ : Веселка, 2000. 325 с.

7. Кудрявцев М. Своє і чуже : історико-літературознавчі та компаративістичні студії. Кривий Ріг, 2007. $368 \mathrm{c}$.

8. Номис М. Українські приказки, прислів’я і таке інше. Київ : Либідь, 1993. 765 с.

9. Откович К. Ілюзія свободи: образ жінки від традиціоналізму до модернізму : монографія. Київ : КАРБОН, 2010. $210 \mathrm{c}$.

10. Словник української мови : в 11-и т. 1977. Т. 8. С. 906 URL: http://ukrlit.org/slovnyk/slovnyk_ ukrainskoi_movy_v_11_tomakh (дата звернення: 04.06.2021).

11. Шалацька Г. Жіночі образи драми «Назар Стодоля» Т. Шевченка у системі духовних цінностей першої половини XIX ст. Шевченкознавчі студії. 2013. Вип. 16. С. 273-282.

12. Шевченко Т. Назар Стодоля. Твори : у 3-х т. / Т. Шевченко. Київ : Держлітвидав, 1963. Т. 2. С. $7-40$.

\section{REFERENCES}

1. Hanzha, D.S., Honiuk, O.V. (2017). Transormatsiya obrazu zhinky v ukrayinskiy literaturi kintsia XIX - pershoyi polovyny XX stolittia [Transformation of a woman image in the Ukrainian literature of late $19^{\text {th }}$ - early $20^{\text {th }}$ century]. In Filolohichni nauky. Zbirnyk naukovykh prats studentiv ta vykladachiv fakultetu. Dnipro: Aktsent.

2. Demchenko, I. (2001). Osoblyvosti poetyky Olgy Kobylianskoyi [The peculiarities of Olga Kobylianska's literary style]. Kyiv: Tvim inter.

3. Yevshan, M. (2009). Zhinka v ukrayinskiy literaturi. Zhony ruskiye [A woman in the Ukrainian literature. Russian wives]. Dyvoslovo, 5, P. 57-60.

4. Yefremov, S. (1995). Istoriya ukrayinskoho pysmenstva [History of the Ukrainian literature]. Kyiv: Femina.

5. Kobylianska, O. (2020). Zemlya: povist [Land: novel]. Kyyiv: Znannya.

6. Kotliarevskyi, I.P. (2000). Eneyida; Natalka Poltavka: pyesa [Eneyida; Natalka Poltavka: play]. Kyiv: Veselka.

7. Kudryavtsev, M. (2007). Svoye i chuzhe: istoryko-literaturoznavchi ta komparatyvistychni studiyi [Nataional and foreign: historical, literary and comparative studies]. Kryvyi Rih: Vydavnychyy dim.

8. Nomys, M. (1993). Ukrayinski prykazky, pryslivya i take inshe [Ukrainian proverbs, sayings etc.]. Kyiv: Lybid.

9. Otkovych, K. (2010). Iliuziya svobody: obraz zhinky vid tradytsionalizmu do modernizmu: monohrafiya [The illusion of freedom: the image of a woman from traditionalism to modernism: a monograph]. Kyiv: KARBON

10. Slovnyk ukrayinskoyi movy: v 11 tomakh [Dictionary of the Ukrainian language: in 11 volumes] (1977). Volume 8. P. 906. URL: http://ukrlit.org/slovnyk/slovnyk_ukrainskoi_movy_v_11_tomakh (accessed 04.06.2021).

11. Shalatska, H. (2013). Zhinochi obrazy dramy "Nazar Stodolia" T. Shevchenka u systemi dukhovnykh tsinnostey pershoyi polovyny XIX st. [Female images in the drama "Nazar Stodolya" by T. Shevchenko in the system of spiritual values of the first half of the $19^{\text {th }}$ century]. Shevchenkoznavchi studiyi, 1, 273-282.

12. Shevchenko, T. (1963). Nazar Stodolia. Tvory u trokh tomakh [Nazar Stodolia. Works in three volumes]. Kyiv : Derzhlitvydav. V. 2. 